
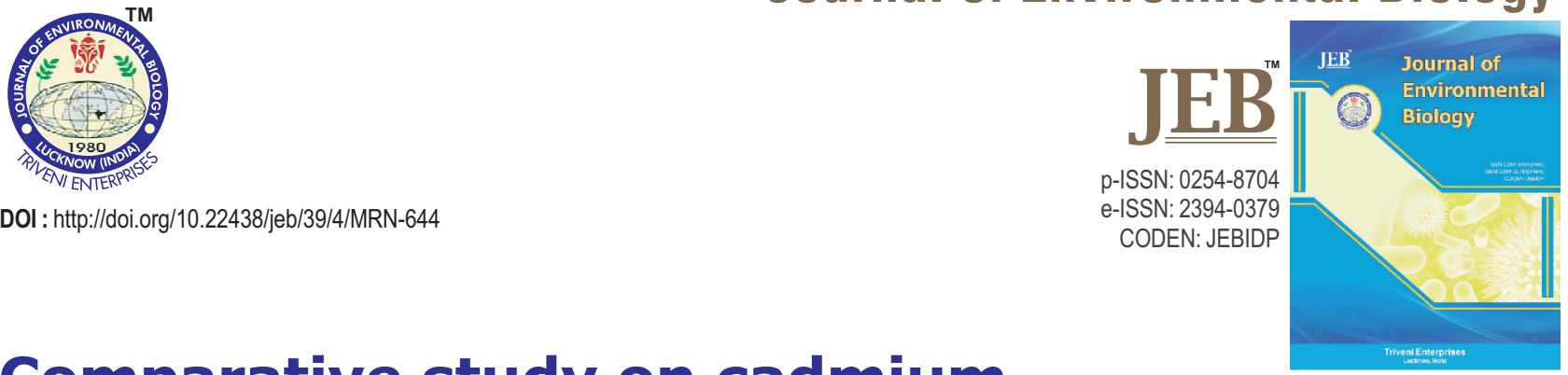

\title{
Comparative study on cadmium accumulation and its toxicity in fish fry of Labeo rohita and Cyprinus carpio
}

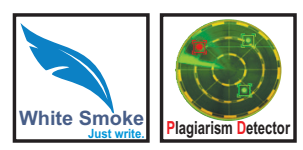

\section{Authors Info}

\section{S.K. Vadlamani ${ }^{1,2}$, C.K.Basuri ${ }^{2}$ and P.R. Yallapragada ${ }^{2 *}$}

'Department of Zoology, Maharajah's Autonomous College, Vizianagaram - 535 002, India

2Department of Zoology, Andhra University, Visakhapatnam - 530 003, India

*Corresponding Author Email : yprabhakararao@yahoo.com

Key words

Cadmium accumulation Cyprinus carpio fry Growth parameters Labeo rohita fry Toxicity

Publication Info

Paper received : 08.05.2017 Revised received: 18.07.2017 Re-revised received: 13.10.2017 Accepted : 13.12 .2017

\section{Abstract}

Aim : Metal contamination in aquatic systems has been getting much attention during last few decades because of its persistent and toxic nature. Since cadmium is one of the most toxic metals, this study was carried out to investigate the tolerance, metal accumulation and growth on the fry of freshwater fishes Labeo rohita and Cyprinus carpio.

Methodology : The fry of Labeo rohita and Cyprinus carpio were collected from fish breeding ponds of Kadiyam and Dwarapudi, East Godavari, Andhra Pradesh, India. The toxic effect of cadmium on fish fry was determined by following static renewal bioassay methods. Growth parameters such as total length, wet weight and dry weight of fish fry were measured when exposed to sub lethal concentration $(0.1998 \mathrm{ppm}$ and $4.938 \mathrm{ppm}$ for L. rohita and $C$. carpio respectively) of cadmium. Metal accumulation was estimated with atomic absorption spectrophotometer.

Results : Initially the $L_{50}$ concentrations of cadmium for the fry of $L$. rohita $(0.994 \mathrm{ppm})$ and C. carpio (24.69 ppm) were determined by exposing them to different concentrations of metal. These studies revealed that the fry of $L$. rohita was more sensitive to cadmium than that of $C$. carpio. When exposed to their sub lethal concentration, the response was different in the fry of both fish. In L. rohita, maximum decrease of $7.3 \%, 10.24 \%$ and $16.32 \%$ was observed in mean length, wet weight and dry weight respectively over their relevant controls at 20 days exposure. In comparison, C. carpio registered more decrease in mean length, wet weight and dry weight $(16.95 \%, 11.2 \%$ and $41.96 \%)$ under similar conditions as above. These results were substantiated by metal accumulation studies.

Interpretation : To determine the impact of

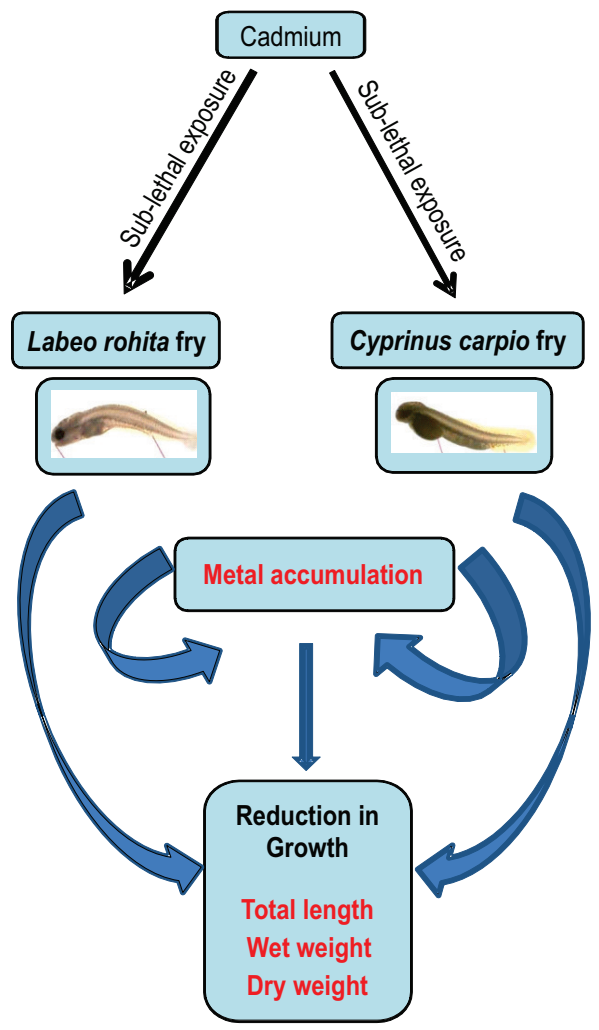
cadmium toxicity, larval phase (fry) should be considered as an important stage. Cadmium is known to accumulate in tissues of Labeo rohita and Cyprinus carpio fry resulting in reduction of growth significantly with respect to their control. 


\section{Introduction}

Cadmium is one of the heavy metals that cause major hazards because of its toxicity, persistence and bioaccumulation in the food chain (Cardwell et al., 2013). Its presence was reported in the water samples of Kolleru Lake (Adhikari et al., 2009) and Godavari River (Ray et al., 2006) on east coast of India where aquaculture is carried out predominantly and these are the potential grounds for fish breeding and rearing ponds. As the pollution levels are constantly increasing in the aquatic environment due to organic wastes, paper mill effluents, wastes from food units and heavy metals from nearby industries (Amaraneni and Pillali, 2001), the aquatic organisms develop safety mechanisms to safe guard themselves against pollutants only up to a certain level. Hence, a study on the tolerance of a particular species to a specific toxicant is a pre-requisite to understand the nature of tolerance. The ability of biota to safeguard themselves from pollutants differs in various species. However, heavy metals are considered as a major source of environmental pollution (Wood, 2001). It is well documented that cadmium is a highly toxic metal for human and animal health (Bressler et al., 2004; Zaki et al., 2009). Human mediated activities have locally and episodically introduced numerous potentially hazardous metals to the environment since the onset of industrial revolution (Celik et al., 2005; Yang and Rose, 2005; Udosen, 2006). These metals after accumulating in the body of aquatic organisms enters the food chain and causes deleterious effects in humans. The amount of absorption and assembling depends on ecological, physical, chemical and biological condition of the organisms (Jaffar et al., 1998). Most of these metals show bio-magnification and have greater half-life periods because of their non-biodegradability and persistence. Therefore, they exert an extra stress on metabolically active tissues and organs.

In recent years, there has been an increasing interest in the utilization of fishes as bio-indicators to study the integrity of aquatic environmental systems (Naigaga et al., 2011). Fish can be used as bio-indicators of trace metals, since they not only accumulate metals in their bodies but also react to water contamination with alterations of various vital functions. In the absorption process, there are four possible routes for metals to enter into the fish body: through food ingested, simple diffusion of metallic ions through gill pores, through drinking water, and by skin absorption (Sindayigaya et al., 1994). Prolonged toxicity studies are important in the aquatic environment as these organisms generally encounter low metal pollutant concentrations in their habitat for prolonged periods due to long biological half-life of toxicants (Silvestre et al., 2006). Hence, fishes are widely used to evaluate the health of aquatic ecosystems because pollutants build up in the food chain and are responsible for adverse effects in the aquatic ecosystems (Farkas et al., 2002). Therefore, an attempt was made in the present investigation to study the cadmium tolerance of Labeo rohita and Cyprinus carpio fry and to make a comparison of cadmium toxicity between these two species of freshwater major carps. Though investigations were carried out on cadmium toxicity in Labeo rohita and Cyprinus carpio fry earlier (Chattopadhyay et al., 1995; Dutta and Kaviraj, 1996; Abedi et al., 2012), the present study was different in that the size of the fry was very small almost $1 \mathrm{~cm}$. This investigation also provides basic data on exposure concentration of cadmium to the fry of these fishes for physiological studies in relation to growth. Growth measurements of fish such as changes in morphometric traits, body shape, chemical and biochemical composition can be used to provide information on fish performance. In the present investigation, few of the standard morphometric parameters like length, wet weight and dry weight have been considered to evaluate growth in both the fish fry exposed to sub-lethal cadmium in the laboratory.

\section{Materials and Methods}

Collection of fish fry : The fry of Labeo rohita and Cyprinus carpio were collected from fish breeding ponds of Kadiyam $\left(16^{\circ} 55^{\prime} 12^{\prime \prime} \mathrm{N} \& 81^{\circ} 49^{\prime} 59^{\prime \prime} \mathrm{E}\right)$ and Dwarapudi $\left(16^{\circ} 55^{\prime} 56^{\prime \prime} \mathrm{N}\right.$ \& $\left.81^{\circ} 55^{\prime} 26^{\prime \prime} \mathrm{E}\right)$, East Godavari, Andhra Pradesh, India where there was no contamination of heavy metal including cadmium and also bacteria in fish rearing tanks as the farmers followed general biosecurity procedures. They were transferred into plastic containers filled with freshwater and supplied with constant aeration. Earlier experiments were conducted by maintaining the fry under laboratory conditions for two days (Surya kumari et al., 2017). The $\mathrm{pH}$ and temperature of water were maintained at $~ 7.5$ to 8 and $29 \pm 2^{\circ} \mathrm{C}$ respectively. The fish fry were fed with the mixture of rice bran and groundnut oil cake powder twice a day. Excess feed was removed by siphoning with a sterile plastic pipe every day. Analysis was carried out in water and food used for the experiment and there were no traces of cadmium.

Acute toxicity studies : The toxic effect of cadmium on fish fry was determined by following the 'static renewable bioassay' method (APHA, 2000). To evaluate the tolerance response of fish fry, they were exposed to different cadmium concentrations for a period of 96 hrs. Preliminary experiments on tolerance of the fry were carried out to determine the final exposure concentrations. $A$ stock solution of cadmium (1\%) was prepared from $\mathrm{CdCl}_{5} \mathrm{H}_{2} \mathrm{O}$ $(A R)$ in distilled water and required concentrations were prepared from the stock by following the method of Bambang et al., (1995). Depending on the above range finding tests, five concentrations were selected for each species. They were $0.25,0.5,1,2$ and 4 ppm for Labeo rohita fry and 10, 20, 30, 40 and $50 \mathrm{ppm}$ for Cyprinus carpio fry. Twenty five uniform-sized $(0.8-1 \mathrm{~cm})$ fry of each species were exposed in each of the troughs containing 15 of freshwater with the metal toxicant as mentioned above. Care was taken to avoid chlorine contamination in freshwater by storing water for several days with aeration. Parallel controls were maintained without metal toxicant. Temperature $\left(29 \pm 2^{\circ} \mathrm{C}\right)$ and $\mathrm{pH}(7.5$ to 8.0$)$ were monitored in all control and exposed troughs. The freshwater in each trough was renewed every $24 \mathrm{hrs}$ with respective concentration of the toxicant. Dead animals were removed every $24 \mathrm{hrs}$ and mortality rate was recorded. 
Sublethal toxicity studies : The design of the experiment included two groups of fry ( $\sim 500$ Nos.) of $L$. rohita and C. carpio $(0.8-\mathrm{Icm}$ length). The first group served as a control (without metal toxicant) and the other groups as exposed. The exposed group was subjected to a sub lethal $\left(1 / 5^{\mathrm{th}}\right.$ of $\left.96 \mathrm{hrs}_{\mathrm{LC}} \mathrm{L}_{50}\right)$ cadmium concentration of $0.1998 \mathrm{ppm}$ for $L$. rohita fry and $4.938 \mathrm{ppm}$ for $C$. carpio fry for a period of 20 days. Samples ( 25 individuals) were taken from both control and exposed at intervals of $24 \mathrm{hrs}, 48 \mathrm{hrs}, 96 \mathrm{hrs}, 10$ days and 20 days for bioaccumulation as well as growth studies.

Growth studies : Fish fry (25) of each species from control and exposed were isolated at each interval and they were blot dried to remove adhered water. Their total length (from anterior snout tip to the posterior tip of the caudal fin) and wet weights were recorded. The fish fry were then dried individually in an oven at $60^{\circ} \mathrm{C}$ for $48 \mathrm{hrs}$ and their dry weights were taken. The total length was measured in millimeters and digital balance of $0.1 \mathrm{mg}$ sensitivity was used to determine the wet and dry weights. Daily weight gain was calculated using the formulae described by Winberg (1971).

Cadmium accumulation studies : At each interval, the control and exposed fry of each species were sacrificed and dried in an oven at $60^{\circ} \mathrm{C}$ for $48 \mathrm{hrs}$. The dried material was homogenized into a fine powder with mortar and pestle. The powder was stored in glass vials and preserved in desiccators prior to analysis. The analysis of metal content was carried out with dried tissue powder. A known quality of tissue powder of fish fry was taken in Teflon crucibles and placed in the muffle furnace at $600^{\circ} \mathrm{C}$ for about 4-5 hrs to make into ash (George and Kureishy, 1979). The ash obtained was dissolved in a known amount of $0.01 \mathrm{~N} \mathrm{HCl}$. The final cleared colorless solution was used for metal estimation with atomic absorption spectrophotometer (AAS, Zenith 700) and the results were expressed as $\mu g g^{-1} d$.wt.

Statistics : Experiments were repeated five times for bioaccumulation and growth studies. Mean values and standard deviations were calculated for each interval using standard methods. Students 't' test was used to compare control with exposed and also for interspecies comparison (Snedecor and Cochran, 1967).

\section{Results and Discussion}

Tolerance : The results indicate that the mortality rates of both the fish fry increased with the increase in concentration of metal. The linear regression equation obtained for log concentration of exposure and Probit values of percent mortality was $Y=0.656+$ 2.832X with a correlation coefficient of $(r) 0.996$ for $L$. rohita fry and $Y=-1.096+4.377 X$ with a correlation coefficient of $(r) 0.953$ for $C$. carpio fry, respectively. Table 1 shows the different lethal concentrations of cadmium calculated by Probit equation and these values were found to be less for $L$. rohita indicating more sensitivity than C. carpio. The $96 \mathrm{hrs} \mathrm{LC}_{50}$ value was $0.994 \mathrm{ppm}$ for L. rohita fry and $24.69 \mathrm{ppm}$ for fry of $\mathrm{C}$. carpio. Kameswara Rao (1974) suggested that the safe concentration of a toxicant can be calculated as $1 / 100^{\text {th }}$ of the 96 hrs $L_{50}$ value. Accordingly, the safe concentration of cadmium was calculated for both the species and they were $0.00994 \mathrm{ppm}$ or $9.94 \mathrm{\mu g} \mathrm{I}^{-1}$ for L. rohita fry and $246.9 \mu \mathrm{gl}^{-1}$ for fry of $C$. carpio. Cadmium is a trace metal that is potentially toxic to most freshwater organisms, particularly fish (Akan et al., 2009). The heavy metal contamination definitely affects the aquatic life of Labeo rohita and Cyprinus carpio. Hence, environmental monitoring of aquaculture ponds is essential to improve the health of these economic fish (Vinodhini and Narayanan, 2008). Farkas et al. (2002) affirmed that the efficiency of food intake and digestion may also be inhibited in the exposed fry leading to abnormality in growth and metabolic activities. Acute toxicity test and $\mathrm{LC}_{50}$ values are useful for assessing the safe level of toxicity and future monitoring of the environment (Lloyd, 1977). The larval stages, fry and fingerlings of various freshwater fishes such as Mugil cephalus, Cirrhinus mrigala, Channa punctata and Clarius batrachus showed similar effects on exposure to cadmium and other toxicants. Pandey and Saksena (1992) reported $201-340 \mu \mathrm{g} \mathrm{I}^{-1}$ as $96 \mathrm{hrs}^{\mathrm{L} C_{50}}$ value for $L$. rohita fry of

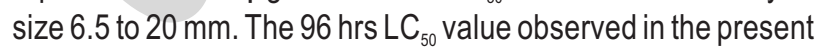
investigation was $0.9964 \mu \mathrm{g} \mathrm{l}^{-1}$ for $L$. rohita fry of $1 \mathrm{~cm}$ size, which was intermediate between the two sizes indicating sizedependent toxicity. Labeo rohita fry having a size of $6.5-20 \mathrm{~mm}$ showed $96 \mathrm{hrs} \mathrm{LC}_{50}$ value of 201 to $175000 \mu \mathrm{g} \mathrm{I}^{-1}$ of cadmium (Chattopadhyay et al., 1995) whereas for Cyprinus carpio fry, the $\mathrm{LC}_{50}$ values were between $165000 \mathrm{\mu g} \mathrm{I}^{-1}$ for $96 \mathrm{hrs}$ and 27100 $\mu \mathrm{Il}^{-1}$ for $48 \mathrm{hrs}$ (Dutta and Kaviraj, 1996).

Cadmium accumulation : A gradual and significant $(P<0.05)$ increase in accumulation of cadmium was observed with increasing exposure time in both the exposed fry when compared to their respective controls at all the intervals. In $L$. rohita fry, a maximum accumulation of $12.58 \mu \mathrm{g} \mathrm{g}^{-1}$ dry weight was observed

Table 1 : Lethal concentrations of cadmium for Labeo rohita and Cyprinus carpio fry

\begin{tabular}{lll}
\hline \multirow{2}{*}{$\begin{array}{l}\text { Lethal } \\
\text { concentrations }\end{array}$} & \multicolumn{2}{c}{ Concentration (ppm) } \\
\cline { 2 - 3 } & L. rohita fry & C. carpio fry \\
\hline $\mathrm{LC}_{5}$ & $0.26 \pm 0.01$ & $10.42 \pm 0.31$ \\
& $(0.25-0.28)$ & $(10.11-10.72)$ \\
$\mathrm{LC}_{10}$ & $0.35 \pm 0.01$ & $12.60 \pm 0.34$ \\
& $(0.33-0.37)$ & $(12.26-12.94)$ \\
$\mathrm{LC}_{25}$ & $0.58 \pm 0.011$ & $17.36 \pm 0.34$ \\
$\mathrm{LC}_{50}$ & $(0.55-0.59)$ & $(17.02-17.7)$ \\
& $0.99 \pm 0.02$ & $24.69 \pm 0.39$ \\
$\mathrm{LC}_{75}$ & $(0.96-1.03)$ & $(24.37-25.01)$ \\
& $1.72 \pm 0.03$ & $35.12 \pm 0.32$ \\
$\mathrm{LC}_{90}$ & $(1.66-1.79)$ & $(34.80-35.44)$ \\
& $2.82 \pm 0.07$ & $48.41 \pm 0.95$ \\
& $(2.67-2.96)$ & $(47.46-49.4)$ \\
\hline
\end{tabular}

Each value represents the concentration \pm S.E. The values in the parenthesis represent $95 \%$ fiducial limits 

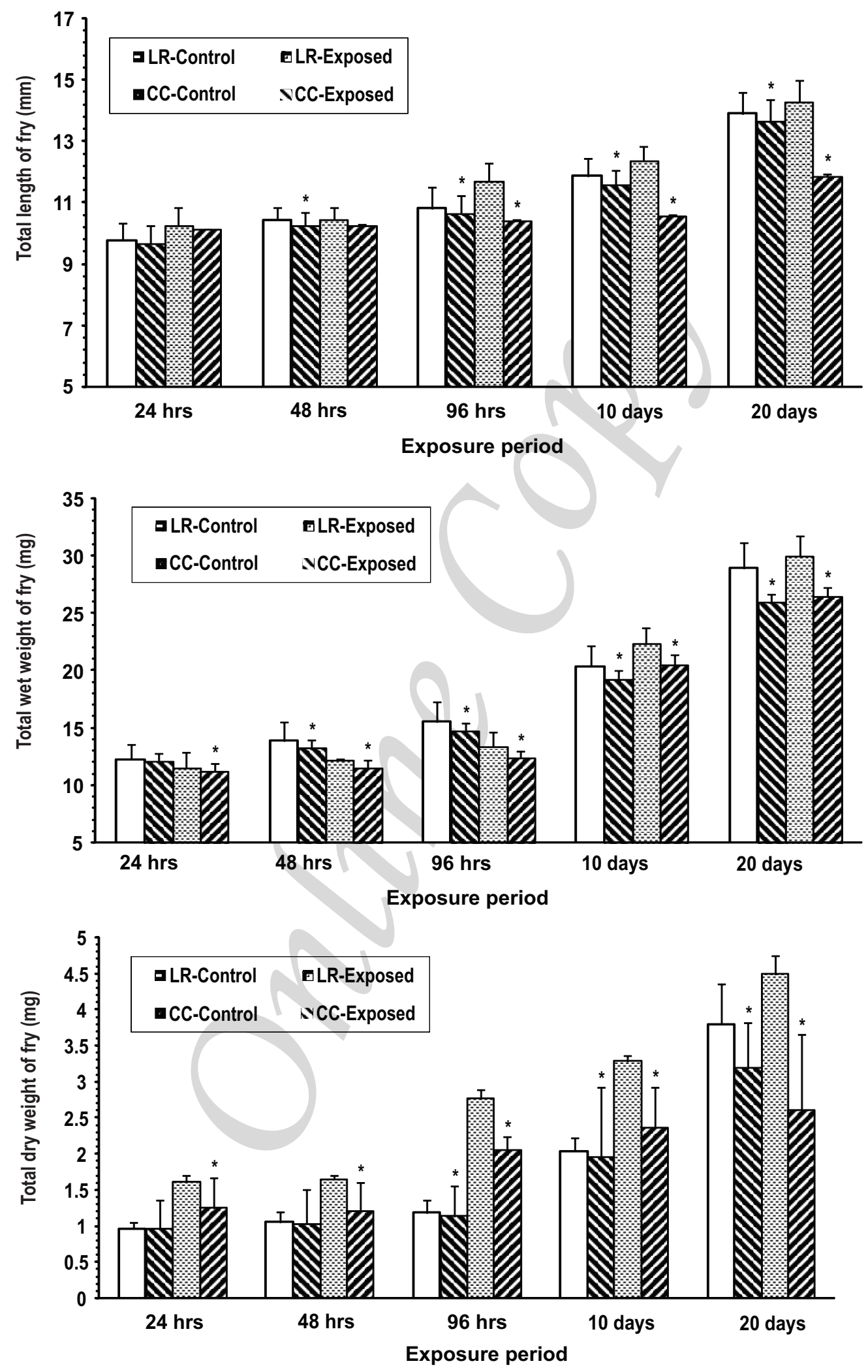

Fig.1 : Total length, wet weight and dry weight in fry of Labeo rohita and Cyprinus carpio exposed to sub-lethal concentrations of cadmium; *Significantly different from their respective controls at $P<0.05$ 
Table 2 : Comparison of weight gain in Labeo rohita and Cyprinus carpio fry on exposure to sub-lethal concentrations of cadmium

\begin{tabular}{|c|c|c|c|c|}
\hline \multirow{3}{*}{$\begin{array}{l}\text { Period of } \\
\text { exposure }\end{array}$} & \multicolumn{4}{|c|}{ Weight gain (mg per day) } \\
\hline & \multicolumn{2}{|c|}{ L. rohita fry } & \multicolumn{2}{|c|}{ C. carpio fry } \\
\hline & Control & Exposed & Control & Exposed \\
\hline $24 \mathrm{hrs}$ & $0.137 \pm 0.013$ & $\begin{array}{l}0.124 \pm 0.014^{*} \\
(8.95)\end{array}$ & $0.373 \pm 0.102$ & $\begin{array}{l}0.117 \pm 0.032^{*} \\
(68.40)\end{array}$ \\
\hline $48 \mathrm{hrs}$ & $0.134 \pm 0.03$ & $\begin{array}{l}0.105 \pm 0.003^{*} \\
(21.82)\end{array}$ & $0.399 \pm 0.063$ & $\begin{array}{l}0.107 \pm 0.017^{*} \\
(73.20)\end{array}$ \\
\hline $96 \mathrm{hrs}$ & $0.114 \pm 0.012$ & $\begin{array}{l}0.108 \pm 0.001^{*} \\
(5.08)\end{array}$ & $0.531 \pm 0.076$ & $\begin{array}{l}0.327 \pm 0.047^{*} \\
(66.20)\end{array}$ \\
\hline 10 days & $0.187 \pm 0.017$ & $\begin{array}{l}0.172 \pm 0.007^{*} \\
(7.98)\end{array}$ & $0.465 \pm 0.034$ & $\begin{array}{l}0.215 \pm 0.021^{*} \\
(53.70)\end{array}$ \\
\hline 20 days & $0.318 \pm 0.002$ & $\begin{array}{l}0.219 \pm 0.018^{*} \\
(31.11)\end{array}$ & $0.352 \pm 0.022$ & $\begin{array}{l}0.167 \pm 0.012^{*} \\
(52.40)\end{array}$ \\
\hline
\end{tabular}

Each value represents mean \pm S.D. The values in the parenthesis represent percent decrease over their respective controls. *Significantly different from their respective controls at $\mathrm{P}<0.05$

at 20 days whereas $C$. carpio fry showed an accumulation of $75.36 \mu \mathrm{g} \mathrm{g}^{-1}$ dry weight on exposure to 20 days. Though both the fry exhibited accumulation on exposure to their respective sub lethal concentration of cadmium, the accumulation was high in $C$. carpio fry than $L$. rohita fry. Accumulation of cadmium in muscle tissue of Cyprinus carpio was noticed by Pedram et al. (2011) while studying the effects of water borne cadmium. Similar bioaccumulation of cadmium was also reported in Cyprinus carpio by Vinodhini et al. (2008). Jaffar et al. (1998) observed heavy metal accumulation in some select local fishes of Pakistan. Similar accumulation of cadmium in tissues of six freshwater fishes was reported by Akan et al. (2009). According to Cardwell et al. (2013) heavy metals like cadmium bioaccumulate and magnify in the aquatic ecosystem causing deleterious effects.

Growth parameters : The results on growth parameters such as mean total length, wet weight and dry weight of exposed fish fry of $L$. rohita and $C$. carpio against their respective controls are presented in Fig. 1. The data indicate a significant decrease $(p<0.05)$ in all growth parameters from 96 hrs on wards in the exposed fry of both $L$. rohita and $C$. carpio over their respective controls. A maximum decrease of $7.3 \%, 10.24 \%$ and $16.32 \%$ was observed in mean length, wet weight and dry weight respectively over their respective controls on 20 days exposure of $L$. rohita fry to sub lethal cadmium. In comparison, C. carpio fry registered more decrease in mean length, wet weight and dry weight (16.85 $\%, 11.2 \%$ and $41.96 \%$ ) over their respective controls on 20 days exposure. A significant decrease $(P<0.05)$ in the daily weight gain was noticed in the exposed fry over their respective controls from 24 hrs onwards in both the fish fry (Table 2). Further \& higher decrease in daily weight gain (52.45) was observed in C. carpio fry compared to $L$. rohita fry $(31.11 \%)$. A reduction in total length, wet weight, dry weight and weight gain in exposed fry over their respective controls was observed in the fry of Labeo rohita and
Cyprinus carpio on exposure to sub lethal cadmium for 20 days. The relative toxicity of cadmium on various parameters was total length < wet weight < dry weight < weight gain in fry of Labeo rohita and wet weight < total length < dry weight < weight gain in fry of Cyprinus carpio which means that the effect was more on total length followed by wet weight, dry weight and weight gain in Labeo rohita, whereas in Cyprinus carpio the effect was more on wet weight followed by total length, dry weight and weight gain. The maximum growth reduction in the Labeo rohita and Cyprinus carpio under short term exposure ( $96 \mathrm{hrs}$ ) to cadmium was $7.3 \%$ and $10.1 \%$, respectively and this could be due the deleterious effect of cadmium on metabolic activity and decrease in food intake and assimilation (Marr et al., 1995; Waiwood and Beamish, 1978). Growth retardation in the fry of Labeo rohita and Cyprinus carpio might be also due to the interaction of metal toxicant accumulated in the tissues of these fries with the enzymes of metabolic pathway and inhibiting normal biochemical functions, which ultimately increase metal stress and decrease energy levels of the fry when compared with control. Cherian and Goyer (1978) reported that cadmium binds irreversibly with sulphydryl groups of catalytic proteins and inhibits normal biochemical functions. Dhavale et al. (1988) suggested that the capacity of a fresh water organism to resist metal stress, however, depends on its energetic efficiency. Hansen et al. (2001) studied the toxic effect of cadmium on juvenile bull trout (Salelinus confluentus) and noticed $28 \%$ reduction in growth of fish exposed to $0.786 \mathrm{\mu g} \mathrm{I}^{-1}$ cadmium for 55 days. Rainbow trout (Oncorhynchus mykiss) also showed growth retardation when exposed to higher concentrations of cadmium compared to control fish (Heydarnejad et al., 2013). A recent study on Anabas testudineus once again proved that cadmium could induce alterations in survival and growth (Rita and Abhik, 2014). Pedram et al. (2011) recorded low growth rate of Cyprinus carpio exposed to 10, 50, $100 \mathrm{ppb}$ of cadmium for 30,60 and 90 days. Low concentrations 
of cadmium and lead (permissible) that are considered as safe, do cause reduction on growth of a grass carp (Ctenopharyngodon idella) (Ahmed et al., 2012). Channa punctatus quality was found to decrease in terms of its protein and glycogen levels due to cadmium toxicity (Sujata and Yashwant, 2015). Recently Pereira et al. (2016) observed hepato-, nephro- and hematological malfunction in catfish Rhamdia quelen when exposed to low levels of cadmium toxicity.

The present study on fry of Labeo rohita and Cyprinus carpio provides a baseline data on tolerance levels of cadmium and it is necessary for the aqua-culturists to monitor water for toxic metals like cadmium before using for fish culture ponds. Fish fry accumulate cadmium even though in sub-lethal quantities and it further undergoes bio-accumulation in the tissues. Hence, fish can be considered as bio-indicator for monitoring the aquatic environment contaminated with cadmium and other heavy metals. The experiments on tolerance and growth also reveal that Labeo rohita fry is more susceptible to cadmium when compared to Cyprinus carpio fry.

\section{Acknowledgments}

This work was supported by University Grants Commission (U.G.C), New Delhi, India. The authors are grateful to the Department of Zoology, Andhra University for providing the research facilities.

\section{References}

Abedi, Z., M. Khalesi, S.K. Eskandari and H. Rahmani: Comparison of lethal concentration of $(\mathrm{LC50}-96 \mathrm{H})$ of $\mathrm{CdCl}_{2}, \mathrm{CrCl}_{3}$ and $\mathrm{Pb}\left(\mathrm{NO}_{3}\right)_{2}$ in common carp (Cyprinus carpio and Sutchi catfish (Pangasius Hypothalamus). Iranian J. Toxicol., 6, 672-680 (2012).

Adhikari, S., L. Gosh, B.S. Giri and S. Ayyappan: Distributions of metals in the food web of fish ponds of Kolleru Lake, India. Ecotoxicol. Environ. Saf., 72, 1242-1248 (2009).

Ahmed, M.S., K.S. Ahmed, R. Mehmood, H. Ali and W.A. Khan: Low dose effects of cadmium and lead on growth in fingerlings of a vegetarian fish, grass carp (Ctenopharyngodon idella). J. Animal Plant Sci., 22, 902-907 (2012).

Akan, J.C., F.I. Abdulrahman, O.A. Sodipo and U. Akan: Bioaccumulation of some heavy metals in six freshwater fishes caught from Lake Chad in Doron Buhari, Maiduguri, Borno State, Nigeria. J. Appl. Sci. Environ. Sanit., 4, 103-114 (2009).

Amaraneni, S.R and P.R. Pillali: Concentration of pesticide residues in tissues of fish Kolleru Lake in India. Environ. Toxicol., 16, 550-556 (2001).

American Public Health Association (APHA): Standard Methods for the Examination of water and wastewater. $20^{\text {th }}$ Edn., American Water Works Association and Water Pollution Control Federation, Washington DC (2000).

Bambang, Y., P. Thuet, M. Charmantier-Daures, J.P. Trilles and G. Charmantier: Effect of copper on survival and osmoregulation of various developmental stages of the shrimp Penaeus japonicas Bate (Crustacea : Decapoda), Aquat. Toxicol., 33, 125-139 (1995).

Bressler, J.P., L. Olivi, J.H. Cheong, Y. Kim and D. Bannon: Divalent metal transporter 1 in lead and cadmium transport. Ann. N. Y. Acad. Sci., 1012, 142-152 (2004).
Cardwell, R.D., D.K. Deforest and W.J. Adams: Do Cd, Cu, Ni, Pb and Zn biomangify in aquatic ecosystems? Rev. Environ. Contam. Toxicol., 226, 101-122 (2013).

Celik, A., A.A Kartel, A. Akdogan and Y. Kaska: Determining the heavy metal pollution in Denizil (Turkey) by using Robinio psendo-acacia L. Environ. Sci. Technol., 31, 105-112 (2005).

Chattopadhyay, S.K., Anam and A.K. Aditya: Bioassay evaluation of acute toxicity of mercuric chloride and cadmium chloride on early growing stages of Labeo rohita. J. Ecobiol., 7, 41-47 (1995).

Cherian, M.G. and R.A. Goyer: Metallothioneins and their role in the metabolism and toxicity of metals. Life Sc., 23, 1-10 (1978).

Dhavale, D.M., V.B. Masurekar and B.A. Giridar: Cadmium induced inhibition of $\mathrm{Na}+/ \mathrm{K}+-\mathrm{ATP}$ ase activity in tissues of crab Scylla serrata. Bull. Environ. Contam. Toxicol., 40, 759-763 (1988).

Dutta, T.K. and A. Kavi Raj : Effects of lime acclimation on the susceptibility of two freshwater teleosts and one oligochaete worm to metallic pollutant cadmium. J. Folia Biol., 44, 143-148 (1996).

Farkas, A., J. Salanki and A. Specziar: Relation between growth and the heavy metal concerntration in organs of bream Abramis brama, $L$. populating lake balaton. Arch. Envi. Contam. Toxicol., 43, 236 (2002).

George, M.D. and T.W. Kureishy: Trace metals in zooplankton from the Bay of Bengal. Indian J. Mar. Sci., 8, 190-192 (1979).

Hansen, J.A., P.G. Welsh, J. Lipton, D. Cacela and A.D. Dailey: The relative sensitivity of bull trout (Salvelinus confluentus) and rainbow trout (Oncorhynchus mykiss) to acute exposures of cadmium and zinc. Environ. Toxicol. Chem., 21, 67-75(2002).

Heydarnejad, M.S., M. Khosravian-Hemamai and A. Nematollahi: Effects of cadmium at sub-lethal concentration on growth and biochemical parameters in rainbow trout (Oncorhynchus mykiss). Irish Veteri. J., 66, 11 (2013).

Jaffar, M., M. Ashraf and Rasoal: Heavy metal contents in some selected local fresh water fish and relevant water. Pakistan J. of Sci. Ind. Res., 31, 189-193(1998).

Kameswara Rao, K.: The comparative toxicities of organophosphorus and carbamate pesticides. Mahasagar, 7, 79-82 (1974).

Lloyd, R.: Are short term toxicity tests a dead end ? Proc. Assoc. Adv. Sci. Aston, 102-109(1977).

Marr, J.C.A., H.L. Bergman, J. Lipton and C. Hogstrand: Differences in relative sensitivity of native and metals-acclimated brown and rainbow trout exposed to metals representative of the Clark Fork River, Montana. Canadian J. of Fish. Aqu. Sci., 52, 2016-2030 (1995).

Naigaga, I., H. Kaiser, W.J. Muller, L. Ojok, D. Mbabazi, G. Magezi and E. Mhuhmuza: Fish as bioindicators in aquatic environmental pollution assessment: A case study in Lake Victoria wetlands, Uganda. Phys. Chem. Earth., 36, 918-928 (2011).

Pandey, R. and D.N. Saxena: The toxocity of copper sulphate to the fingerlings of Labeo rohita. Bull. Env. Sci., 10, 23 (1992).

Pedram, M., A. M Ali, H. Rahim and E. Esa: Short and long-term effects of waterborne cadmium on growth and its muscle accumulation in common carp fish (Cyprinus carpio), an experimental study. Turkish J. of Fish. Aqu. Sci., 11, 587-593 (2011).

Pereira, L.S., J.L.C.Ribas, T.Vicari, S.B.Silva, J.Stival, A.P.Baldan, F.X.Valdez Domingos, M.T. Grassi, M.M. Cestari and H.C. SilvadeAssis: Effects of ecologically relevant concentrations of cadmium in a freshwater fish. Ecotoxicol. Environ. Saf., 130, 29-36 (2016).

Ray, A.K., S.C. Tripathy, S. Patra and V.V. Sarma: Assessment of Godavari estuarine ecosystem through trace metal studies. Environ. Int., 32, 219-223 (2006). 
Rita, C. and G. Abhik: Effects of cadmium and copper on survival and growth of Anabas testudineus. Res. J. Chem. Environ. Sci., 2, 103108 (2014).

Silvestre, F., J. Dierick, V. Dumont, M. Dieu, M. Raes and P. Devos: Differential protein expression profiles in anterior gills of Eriocheir sinensis during acclimation to cadmium. Aqua. Toxic., 76, 46-58 (2006).

Sindayigaya, E.R., H. Van Cauwenbergh, Robberecht and H. Deelstra: Copper zinc, manganese, iron, lead, cadmium, mercury and arsenic in fish from lake. Tanganyika, Burundi. Sci. of the total Environ., 144, 103-115(1994).

Snedecor, G.W. and W.G. Cochran : Statistical Methods. $6^{\text {th }}$ Edn., lowa State University Press:Ames (1967).

Sujata, K. and K. Yashwant: Impact of cadmium on the biochemical contents in certain tissues of freshwater fish, Channa punctatus (BLOCH). World J. Pharm. Pharmaceu. Sci., 4, 1430-1441 (2015).

Surya Kumari, V., B. Charan Kumar and Y. Prabhakara Rao. Cadmiuminduced alterations in bio-chemical constituents of Labeo rohita and Cyprinus carpio fry: A comparative study. Int. J. Bioass., 6, $5389-5393(2017)$.

Udoson, E.O.: Determination of trace metals and fluxes in sediments along a segment of Qualbeo River in Southern Nigeria. J. Natu. Appl. Sci., 2, 82-90 (2006).

Vinodhini, R. and M. Narayanan: Bioaccumulation of heavy metals in organs of fresh water fish Cyprino carpio (common carp). Int. J. Environ. Sci. Techno., 5, 179-182(2008).

Waiwood, K.G. and F.W.H. Beamish: The effects of copper, hardness and $\mathrm{pH}$ on the growth of rainbow trout, Salmo gairdneri. J. Fish Bio., 13, 591-598 (1978).

Winberg, G.C.: Methods for the Estimation of Production of Aquatic Animals. Academic Press, New York (1971).

Wood, C.M.: Toxic responses of the gill. In: Target Organ Toxicity in Marine and Freshwater Teleosts, Organs (Eds.: D. W. Schlenk and W. H. Benson). Taylor and Francis, Washington, DC, pp. 1-89 (2001).

Yang, H. and N.L. Rose: Trace element pollution records in some UK lake sediment, their history, influence factor and regional differences. Environ. Sci. Technol., 31, 63-75(2005).

Zaki, M.S. S.O. Mostafa, O.M. Fawzi, M. Khafagy and F.S. Bayumi: Clinicopathological, biochemical and microbiological change on grey mullet exposed to cadmium chloride. American-Eurasian $\mathrm{J}$. Agri. Environ. Sci., 5, 20-23 (2009). 